\title{
14. VARVE CHRONOLOGY: ESTIMATED RATES OF SEDIMENTATION IN THE BLACK SEA DEEP BASIN
}

\author{
Egon T. Degens, Hamburg University, Hamburg, Germany, \\ Peter Stoffers, Heidelberg University, Heidelberg, Germany, \\ Stjepko Golubić, Boston University, Boston, Massachusetts, USA \\ and \\ Mike D. Dickman, Brock University, St. Catharine's, Ontario, Canada
}

\begin{abstract}
Various varve types and their implication in estimating rates of sedimentation in the Black Sea Basin are discussed. Average modern denudation rates in the Black Sea source area are estimated at $0.063 \mathrm{~mm} / \mathrm{yr}$ or about $100 \mathrm{t} / \mathrm{km}^{2} / \mathrm{yr}$. The stripped detritus would yield a sediment blanket of $0.4 \mathrm{~mm} / \mathrm{yr}$ if spread evenly over the entire bottom of the Black Sea. Siliceous and calcareous remains of planktonic production would give additional increment, raising the average thickness close to $0.5 \mathrm{~mm} / \mathrm{yr}$. This value is representative for steppe vegetation. At times of forest vegetation, the denudation rate is lowered by more than half. Applying compaction effects, and assuming similar orographic relationships for the Pleistocene, the mean rate of deposition is $20 \mathrm{~cm} / 10^{3} \mathrm{yr}$. Since slumping and turbidity currents would eventually carry the bulk of the detritus to the deep basin, the sedimentation rate would almost double there. At times of glacial melting and loess mobilization, sedimentation rates could be as high as $10 \mathrm{~m} / 10^{3} \mathrm{yr}$. Rapid subsidence of the basin floor would also induce pulses of turbidites.
\end{abstract}

\section{RATE OF DENUDATION IN BLACK SEA SOURCE AREA}

At present, the Black Sea is a gigantic catch basin for the river discharge of half of Europe and part of Asia (Figure 1). The source area is well defined and can be subdivided into several orographic provinces which are distinguished by geography extension, climate, and elevation. The following subdivision seems to be appropriate:

\begin{tabular}{lr}
\multicolumn{1}{c}{ River } & $\begin{array}{r}\text { Size of Drainage } \\
\text { Area }\left(\mathrm{km}^{2}\right)\end{array}$ \\
\cline { 2 - 2 } 1. Danube & \\
2. Dnestr & 836,000 \\
3. Y. Bug & 61,900 \\
4. Dnepr & 34,000 \\
5. Don & 538,000 \\
6. Kuban & 446,000 \\
7. Caucasian Rivers & 63,500 \\
8. Rioni & 24,100 \\
9. Coruh & 15,800 \\
10. Turkish Rivers & 16,700 \\
11. Bulgarian Rivers & 231,500 \\
Total & 22,200 \\
& $2,290,200$
\end{tabular}

These figures are accurate within a few percent; they represent only the planar projection of the individual terrain and not the actual surface area exposed to denudation.

The region under study is characterized by its diversity. We encounter all transitions between arid and humid climates and between lowlands and mountainous areas. The issue is further complicated, because the Pripjet swamps, the Panonic flatland, and the lowlands along the Black Sea coast are regions of sedimentation rather than denudation (Paluska and Degens, this volume).

Shimkus and Trimonis (1974) present data on the sediment and salt load which is annually carried by the major rivers into the Black Sea basin. The total load divided by the size of the individual drainage area gives the total amount of yearly denudation in tons per square kilometer (Table 1). From these figures, Degens et al. (1976) derived the mean volume of eroded material, applying some "cosmetic" corrections to account for the areas of sedimentation within the Black Sea source region. The average denudation rate for the entire source is $0.063 \mathrm{~mm} / \mathrm{yr}$ or about $100 \mathrm{t} / \mathrm{km}^{2} / \mathrm{yr}$.

From a sedimentological point of view it is of interest to know at what points most of the detritus enters the Black Sea. Figure 2 illustrates that: (1) the Danube carries about $60 \%$ of the detrital load; (2) the Don and Kuban discharge into the Sea of Asov where the material comes to rest; (3) the Caucasian Rivers, Rioni and Coruh, contribute $20 \%$ of the total detritus; and (4) Dnestr, Y. Bug, Dnepr, and the Bulgarian rivers yield very little material.

\section{HOLOCENE VARVE CHRONOLOGY}

Leg 42B scientists have had the formidable task of making age estimates on sediment cores which, below 


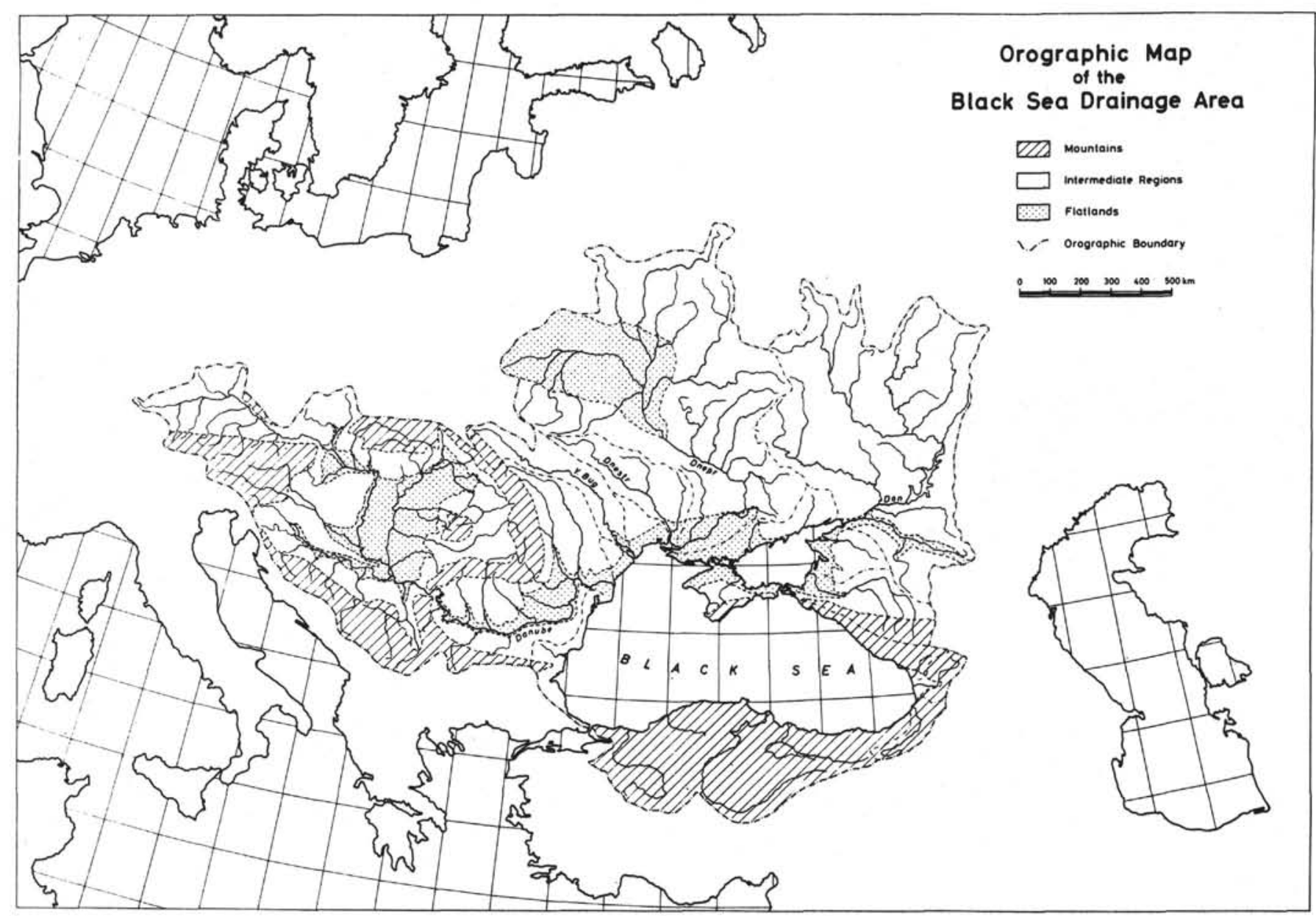

Figure 1. Orographic map of the Black Sea drainage area.

TABLE 1

Denudation in Source Area of Black Sea Basin

\begin{tabular}{lccccccc}
\hline River & $\begin{array}{c}\text { Detritus } \\
\left(10^{6} \mathrm{t} / \mathrm{yr}\right)\end{array}$ & $\begin{array}{c}\text { Salts } \\
\left(10^{6} \mathrm{t} / \mathrm{yr}\right)\end{array}$ & $\begin{array}{c}\text { Total Load } \\
\left(10^{6} \mathrm{t} / \mathrm{yr}\right)\end{array}$ & $\begin{array}{c}\text { Size of Area } \\
\left(\mathrm{km}^{2}\right)\end{array}$ & $\begin{array}{c}\text { Amount } \\
\text { of Weight } \\
\left(\mathrm{t} / \mathrm{km}^{2} \mathrm{yr}\right)\end{array}$ & $\begin{array}{c}\text { Denudation } \\
\text { Volume } \\
\left(\mathrm{m}^{3}\right)\end{array}$ & $\begin{array}{c}\text { Denudation Rate } \\
(\mathrm{mm} / \mathrm{yr})\end{array}$ \\
\hline Donau & 83.00 & 52.51 & 135.51 & $681,000^{\mathrm{b}}$ & 199.0 & 124.4 & 0.125 \\
Dnestr & 2.50 & 2.79 & 5.29 & 61,900 & 85.5 & 53.5 & 0.054 \\
Y. Bug & 0.53 & 1.35 & 1.88 & 34,000 & 55.4 & 34.6 & 0.035 \\
Dnepr & 2.12 & 10.79 & 12.91 & $383,500^{\mathrm{b}}$ & 24.0 & 15.0 & 0.015 \\
Don & 6.40 & 8.43 & 14.83 & 446,500 & 33.2 & 20.8 & 0.021 \\
Kuban & 8.40 & 1.95 & 10.35 & 63,500 & 163.0 & 102.0 & 0.102 \\
Caucasian Rivers & 6.79 & & 7.3 & 24,100 & 303.0 & 189.5 & 0.190 \\
Rioni & 7.08 & 2.16 & 7.6 & 15,800 & 481.0 & 301.0 & 0.301 \\
Coruh & 15.13 & & 16.2 & 16,700 & 971.0 & 607.0 & 0.607 \\
Turkish Coast & 17.00 & 6.70 & 23.70 & 231,500 & 102.4 & 64.0 & 0.064 \\
Bulgarian Coast & 0.50 & 0.80 & 1.30 & 22,200 & 58.5 & 36.6 & 0.037 \\
\hline
\end{tabular}

aData from Shimkus and Trimonis, 1974.

$\mathrm{b}_{\text {Reduced area. }}$

the top 10 meters, are too old for radiocarbon analyses, and which so far have escaped dating by conventional methods such as fossil assemblages or geochemical techniques. The striking varve pattern in some sections of the cores, however, provides a means of age determination, if the pattern can be related to seasonal, annual, or other temporal incidents.
On the basis of radiocarbon dates from Black Sea sediments, it was concluded that the rate of deposition in the deep basin has remained fairly uniform over the past 7000 years, averaging $10 \mathrm{~cm} / 1000$ years (Ross and Degens, 1974). In a recent study (Degens et al., 1976, in press), varve chronology was applied which put in question some of the previous interpretations. It 


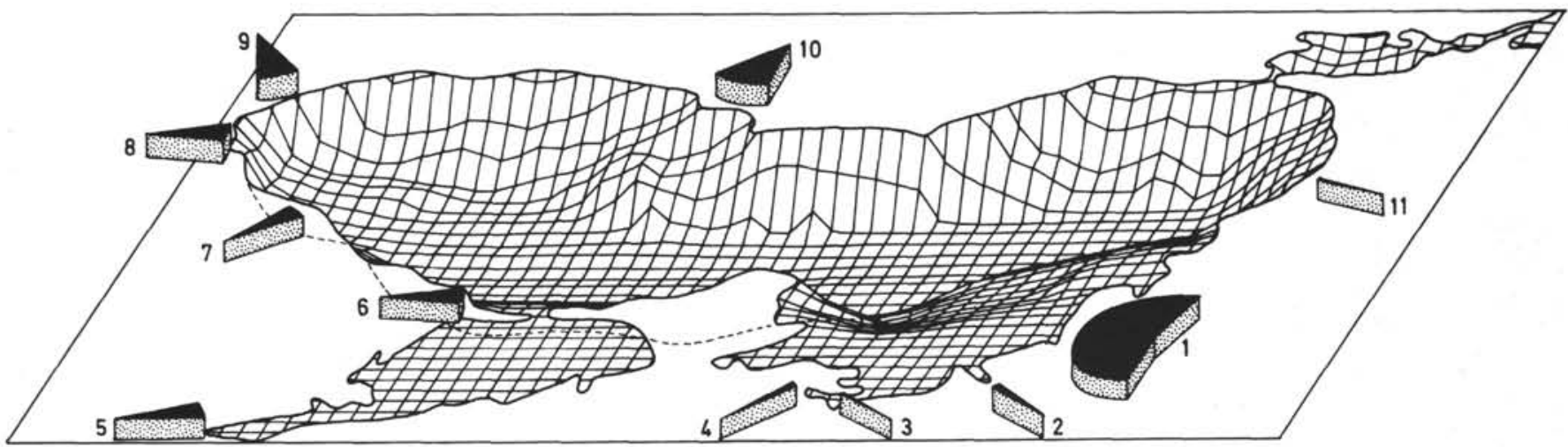

Figure 2. Black Sea catch basin; modern detrital flux expressed in percent of total. Danube (1); Dnestr (2); Y. Bug (3); (4); Don (5); Kuban (6); Caucasian Rivers (7); Rioni (8); Coruh (9); Turkish Rivers (10); and Bulgarian Rivers (11).

appears that recent Black Sea sediments contain a certain amount of dead organic carbon which makes them "older" by 2000 to 3000 years.

The Holocene varves of the deep Black Sea have been described in detail (Ross and Degens, 1974). Light and dark layers alternate regularly, and the pattern is principally caused by seasonal plankton blooms which insert white coccolith bands into a darker matrix (coccolith unit), or fine, almost black bands into a dark brown matrix (sapropel unit). As many as 270 individual bands per meter of core section were counted (Degens et al., 1976), and one double layer represents one year of depositional history.

By counting the number of varves in a series of short cores $(1.5$ to $2 \mathrm{~m})$, several interesting aspects came to light (Figure 3[A, B]). Whereas normal rates of sedimentation are $30 \mathrm{~cm} / 10^{3} \mathrm{yr}$ for the coccolith unit which formed over the past 1000 years, and $10 \mathrm{~cm} / 10^{3} \mathrm{yr}$ for the sapropel unit deposited in the time interval between 1000 and 5000 years B.P. (before present), turbidity currents may carry a substantial amount of detritus to the deep basin. As a result we may find in cores from the basin apron (Figure 3[A], Core Stations 5, 11, and 12) a sediment layer of up to 2 meters thick which, at its base, is only 1.5 to 2000 years old $\left(=1 \mathrm{~m} / 10^{3} \mathrm{yr}\right)$.

One core from the upper basin slope (Figure 3[A], Core Station 35) examined for varves was found to be essentially free of turbidites; probably because a deposit covering about 300 years of sedimentation history was stripped off in the form of a slump about 500 years ago. In this core (Figure 4), sedimentation rates were uniform from 800 B.C. to about 200 A.D. from whereon they increase in a fluctuating fashion to the present. The high "noise level" observed for the past 1500 years can best be accounted for by agricultural activities such as deforestation and the development of a "Kultursteppe." Episodic floods have carried higher amounts of detritus than normal to the Black Sea and have produced the high peaks on the sedimentation curve.

An increase in rate of deposition towards the present is also discernible in a core from the basin apron (Figure 5), where normal sedimentation has been interrupted several times by turbidites. The turbidites, as shown in Figure 3, always occur at the same dateline, although the core locations are as much as $100 \mathrm{~km}$ apart.

The evolution of anoxic conditions during the Holocene is also of significance. Each gram-atom of carbon in plankton requires 1.3 moles of oxygen for its oxidation (Redfield et al., 1963). Since the amount of organic matter that falls through the $\mathrm{O}_{2} \mathrm{H}_{2} \mathrm{~S}$ interface is fairly well known (Deuser, 1971), the decay constant of the oxygen reservoir can be calculated (Deuser, 1974). From this figure, the upward progression of the $\mathrm{O}_{2}-\mathrm{H}_{2} \mathrm{~S}$ interface can be derived. Calculations show that the thermohaline boundary requires about 3000 years to rise from the 2200-meter deep abyssal plain to a water depth of 500 meters. Varve-counting techniques substantiate these findings. Figure 3 (compare Cores 18 and 35 ) shows that finely laminated sapropels started to come in on the basin slope at a depth of 470 meters almost 2300 years after they first appeared on the bottom of the Black Sea basin.

In summary, during the past 5000 years, normal rates of sedimentation in the deep basin were $10 \mathrm{~cm} / 10^{3} \mathrm{yr}$ for the sapropel unit and $30 \mathrm{~cm} / 10^{3} \mathrm{yr}$ for the coccolith unit. Turbidites and slumps supplied substantial amounts of detritus to the central basin and increased rates to $1 \mathrm{~m} / 10^{3} \mathrm{yr}$. In contrast, the sedimentation rate on the upper basin slope is generally three times greater than in the deep basin. There, however, submarine stripping and erosion may have removed material, thereby lowering the actual rates of accumulation. The sapropel unit has formed at times of forest vegetation, whereas the coccolith unit began when agriculture had already transformed the Black Sea source area into a steppe.

\section{VARVE PATTERNS RECOGNIZED IN PLEISTOCENE SEDIMENTS}

The distinct varve pattern of the coccolith and sapropel units discussed in the preceding chapter is repeated only at Site 379 in Hole 379A, Core 11 at a depth of about 100 meters. Stratigraphically, it is in the Eemian (Karangat) Interglacial. Gross inspection of the coccolith and sapropel units reveals rates of deposition identical to their Holocene counterparts, if we take into account some reduction of the core volume through compaction. 


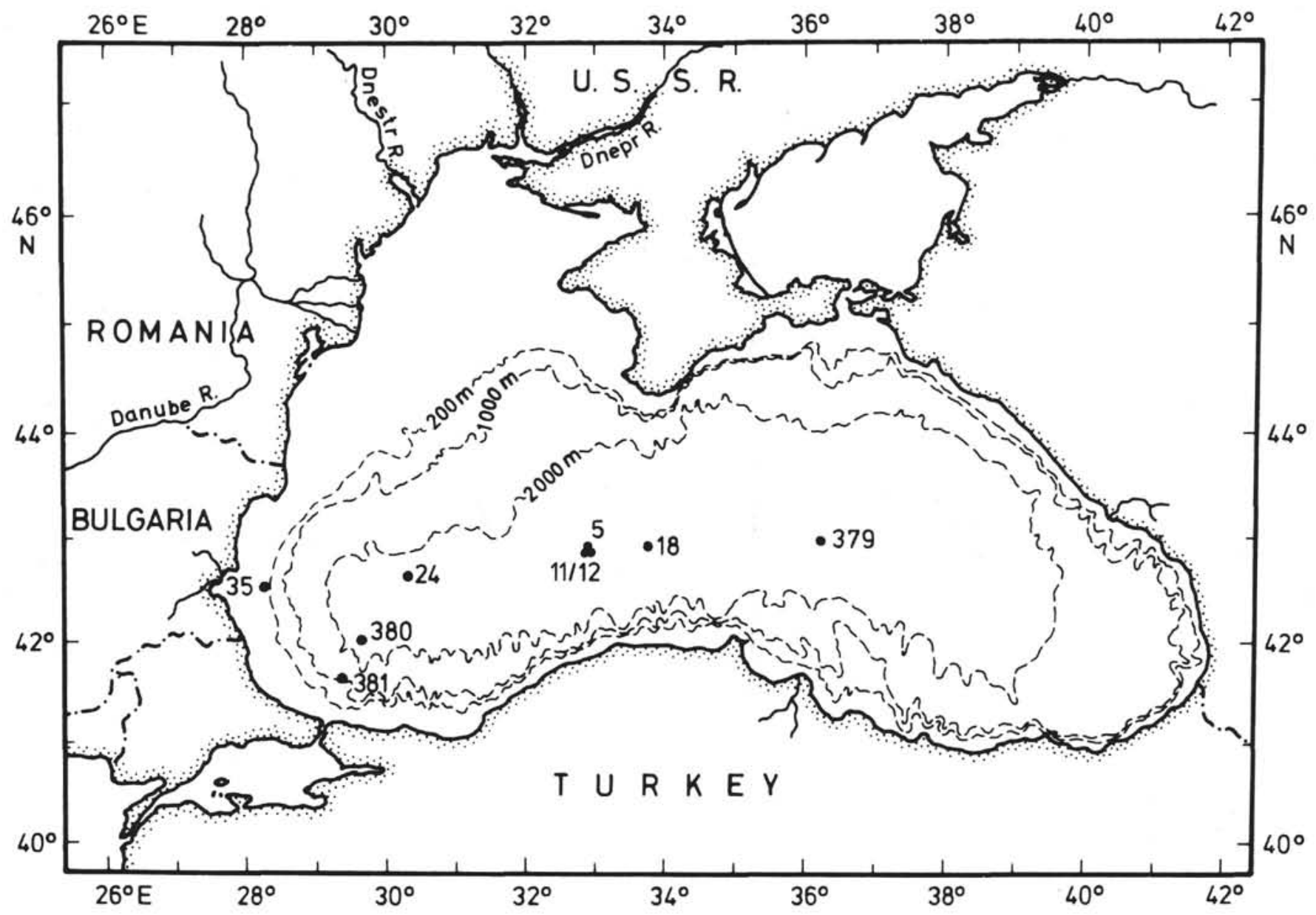

Figure 3. Stratigraphic correlation of short cores taken off the Turkish coast near the Bosporus. For details on core sites, petrography, and varve-counting techniques see Degens et al. (in press). Repeated counts have an error of less than 5 per 1000 double varves $(=5$ years in 1000 years).

Lower in the section, at a depth of about 400 meters, thin carbonate-rich silty sand layers show minute laminations with up to 10 individual white layers per $\mathrm{cm}$. This is almost at the base of the Elster glacial period (Uzunlar-Old Euxin) and the fine layers probably represent windblown loess deposits from Russia. Rates cannot be assigned because the annual frequency of northerly winds is uncertain.

Between about 450 meters at Hole 379A (Core 50) and continuing to its termination at 624 meters, carbonate varves with a repeating pattern of a few $\mathrm{cm}$ to $10 \mathrm{~cm}$ are frequently encountered. Because of their size, we term them "megavarves."

At Hole $380 \mathrm{~A}$ and Site 381 megavarves are sporadically found but compared to Hole $379 \mathrm{~A}$, there are no extended sections. In most instances a few megavarve cycles are intercalated with Seekreide, finely laminated light, and dark carbonate-rich deposits and carbonate-free sapropels. Actually it appears that Seekreide and sapropel are the two end members of a system which, when it fluctuated rapidly, produced finely laminated carbonate and, when moving more slowly, generated megavarves. Massive seekreide and sapropel units formed when the equilibrium shifted to one or the other side.
Typical megavarves and laminated carbonates are depicted in Figures $6 \mathrm{~A}$ and $6 \mathrm{~B}$. The rate of sedimentation for a single megavarve most likely was variable; several years to perhaps a few hundred years were needed to complete a full cycle (see following sections). In contrast, the finely laminated carbonates are most likely annual double varves, with the white layer representing summer precipitation of calcite, and the dark layer the regular organic-rich facies. On the average, 25 double varves per $\mathrm{cm}$ can be counted which implies a rate of sedimentation of $40 \mathrm{~cm} / 10^{3} \mathrm{yr}$. The measured thickness of the laminated carbonate section from Hole $380 \mathrm{~A}$ is about 200 meters. Stratigraphically, this is in the Eburon (Early Cauda) and a fresh-water environment is indicated. Although occasional slumping cannot be ruled out, we feel that most of the section has been deposited without major disturbances in quiet water of moderate depth. Under this assumption, the laminated carbonates would cover a time interval of about 500,000 years ( 1.2 to 1.7 m.y.B.P.) which corresponds to the age assigned by Dutch workers for the Eburon (Hammen et al., 1971; Zagwijn, 1975).

The "classic" Scandinavian varve consists of a light sand layer and a dark clay layer. The sandy layer is formed when the melting causes erosion of larger 


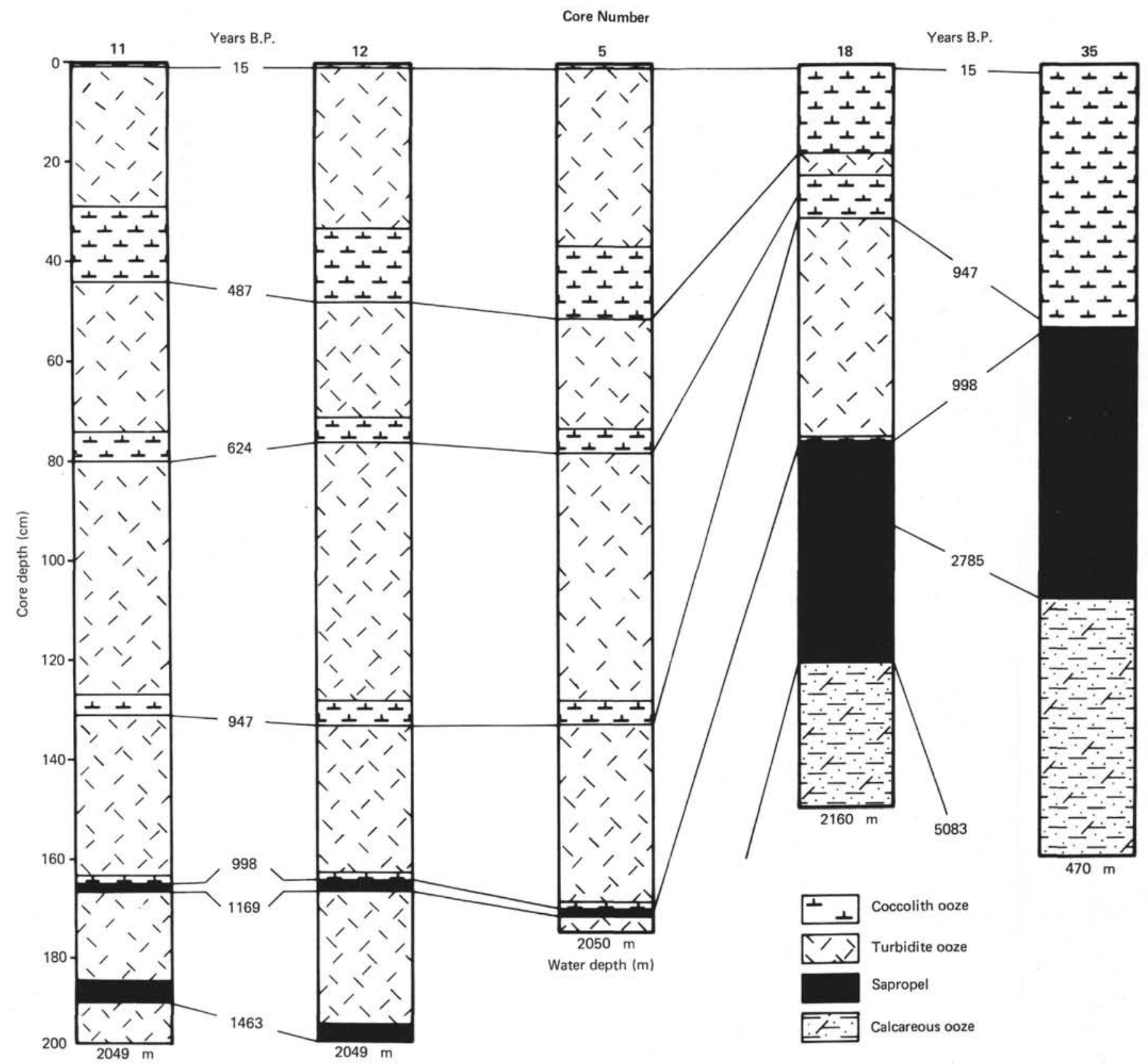

Figure 3. (Continued).

particles, while the dark layer is formed during winter when the runoff volume is reduced. From Hole $380 \mathrm{~A}$ we encounter twice the classical varve pattern at a depth of about 360 and 400 meters (Cores 4 and 8). They formed following cold stages of the Menap (PostCauda) in a post-glacial lake environment. On the average, four dark and four light layers per $\mathrm{cm}$ are present (Figure 6C). The layers are all about the same thickness except for the twelfth light layer which is 2 to 3 times wider than the average layer. Thus while the rates are generally around $2-3 \mathrm{~m} / 10^{3} \mathrm{yr}$, much higher rates may occur (Figure 7).

\section{DESCRIPTION AND ORIGIN OF MEGAVARVES}

In detail, the principal elements of the megavarves from Hole 397A are as follows (Figure 8): (1) light colored carbonate, (2) clay-rich gray layer, (3) laminae of pyrite grains, (4) animal burrows, and (5) occasional coarse-grained sediment. The distribution ratio of Units 1 and 2 is about 1 to 3 , and 20 layers of pyrite grains per meter core length is typical. In adjacent sections of the core similar sedimentation rhythmicity continues without the bioturbated horizons. In these sequences there is a higher incidence of coarser, sorted grain layers (particularly in the white carbonate layers), and ripples and cross-bedded lenses are more common. A typical sequence is illustrated in Figure 9 where pyrite layers of various density and less than $1 \mathrm{~mm}$ in thickness are usually associated with gray layers; finely dispersed pyrite grains are found throughout the gray sediment. Burrows are associated with the boundary between gray and white laminae, usually producing white fillings which contrast against the gray back- 


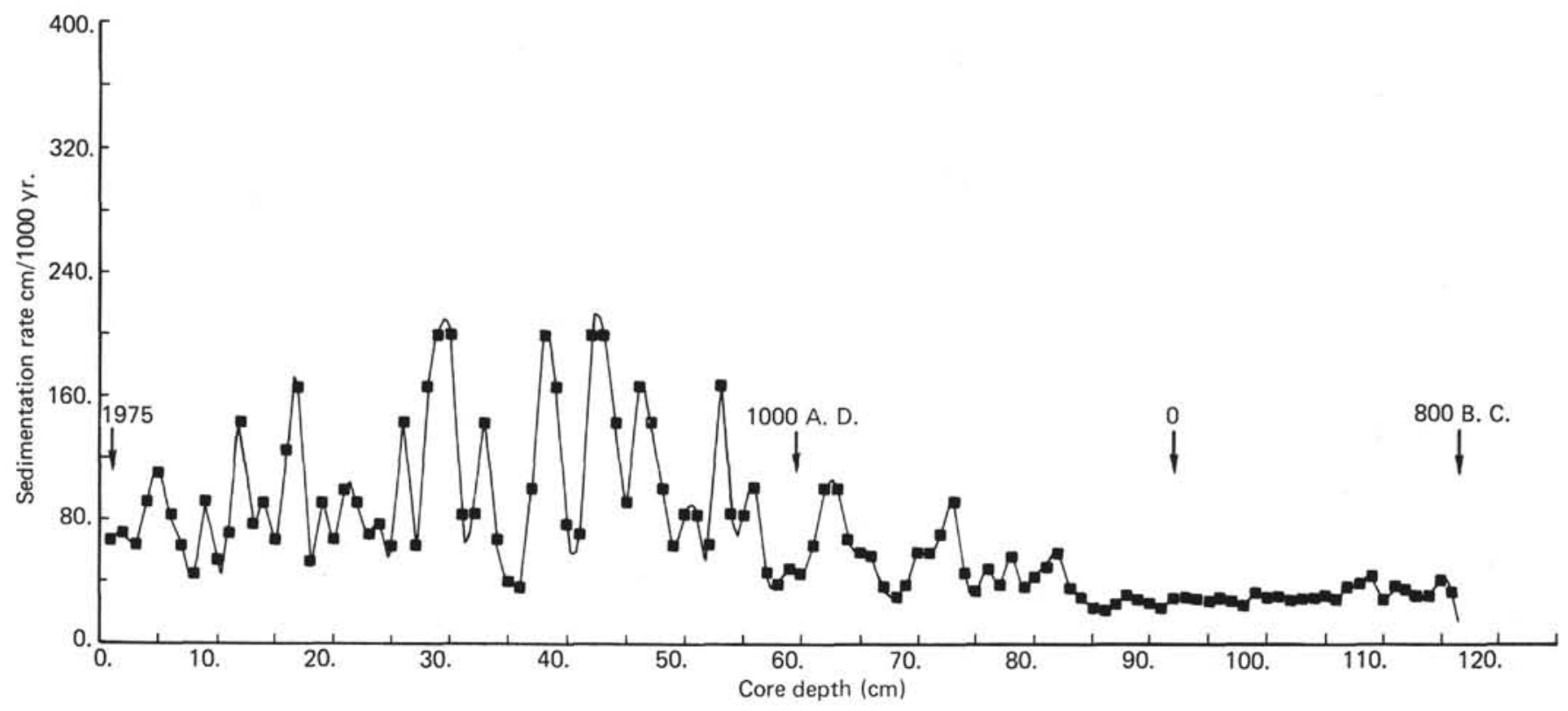

Figure 4. Rates of sedimentation in a sediment core from the Black Sea basin slope at a water depth of 470 meters (Core 35 ; Figure. 3). The age assignment is based on varve counts (1 light and 1 dark layer $=1$ year). It is of note that varve dating of a nearby core which goes back to 4100 B.C. (Core 18; Figure. 3) shows no apparent change in sedimentation rate below 800 B.C.

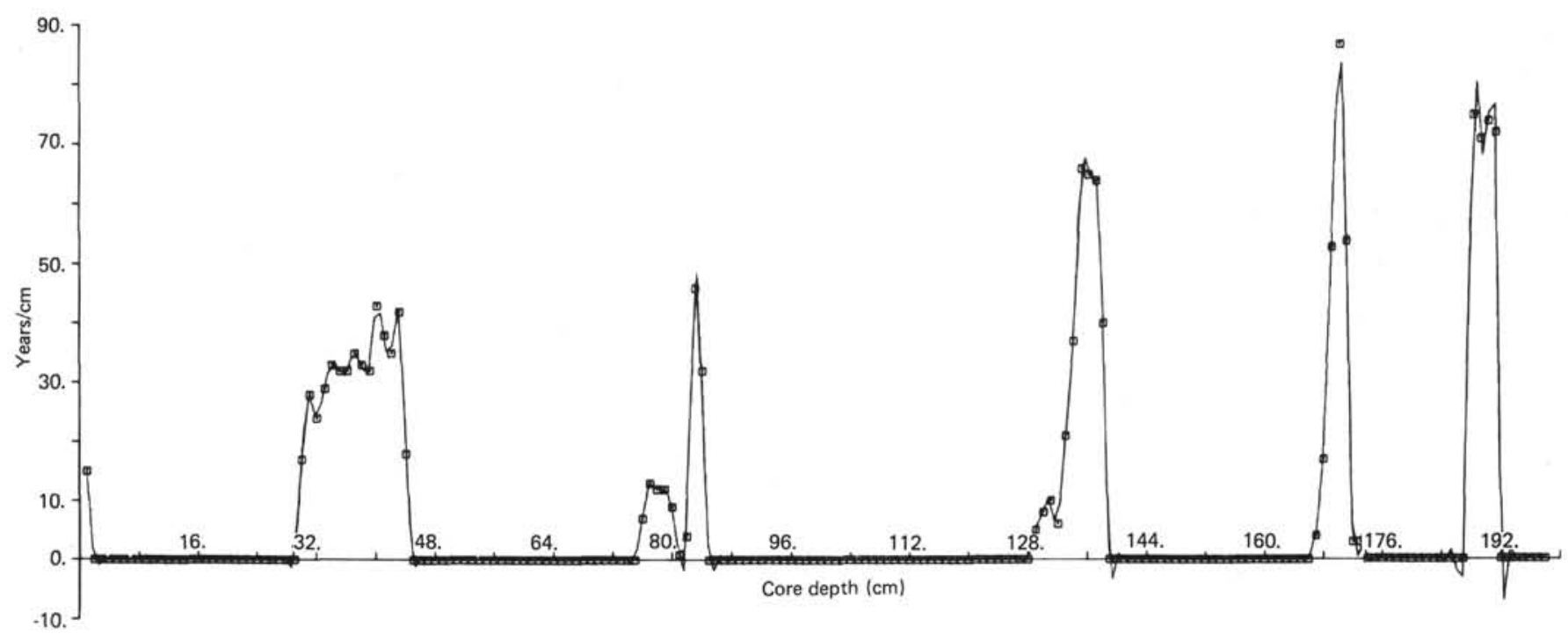

Figure 5. Rates of sedimentation in a sediment core from the Black Sea apron at a water depth of 2049 meters (Core 11; Figure. 3). During the past 1500 years the varve section is 5 times interrupted by turbidites. It is of note that turbidite incidents in three cores $(11,12,5$; Figure. 3) are always synchronous, even though sites are apart by as much as $100 \mathrm{~km}$.

ground of the burrowed matrix. Iron staining along the burrow lining was not observed. Laminae containing coarse-grained material are present.

Variations of this sequence are illustrated in Figure 9(B) which shows a burrow horizon terminated by a pyrite layer; several alternating layers of varying color and grain size inserted between two burrow horizons; and some of the burrow horizons in a sequence are truncated from above.

The shape of burrows has been reconstructed by serial sectioning (Figure 10). They are irregularly curved and run obliquely or parallel to the bedding plane. Branching is frequent, subdichotomous or irregular. The burrow tunnels are 1-2 mm wide, often oval in cross-section with the longer axis parallel to the bedding plane. This shape is in part a consequence of compactional deformation (Crimes, 1975, fig. 7.4). Burrows deeper in the core show a higher degree of flattening.

Bioturbate textures observed in Deep Sea Drilling Program cores from the Caribbean (Kennedy, 1975, fig. 17.6) and the Pacific (Chamberlain, 1975), similar 


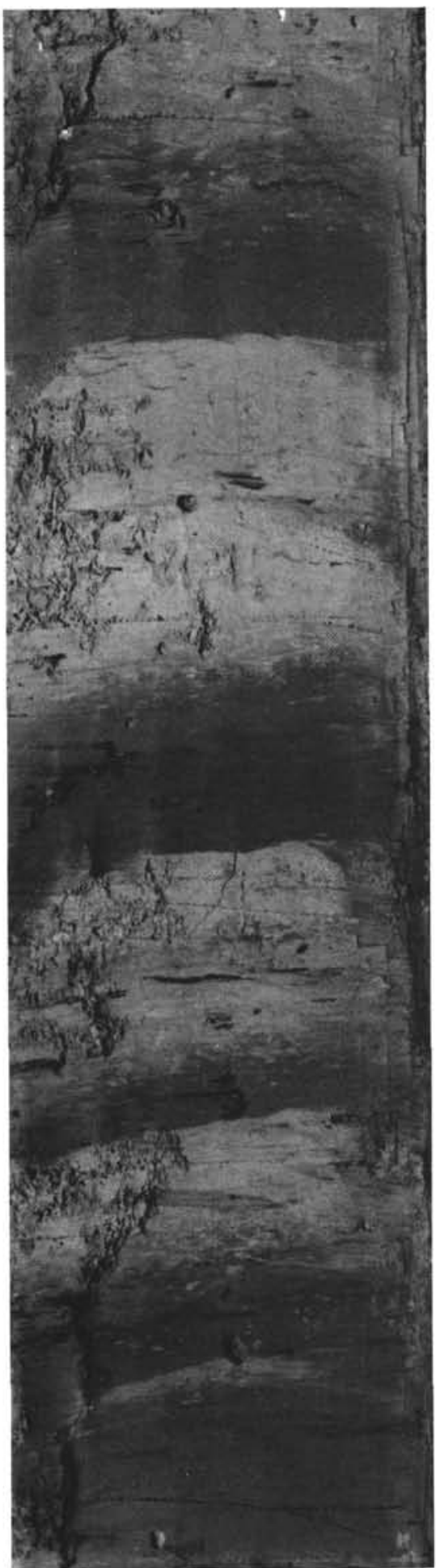

A.

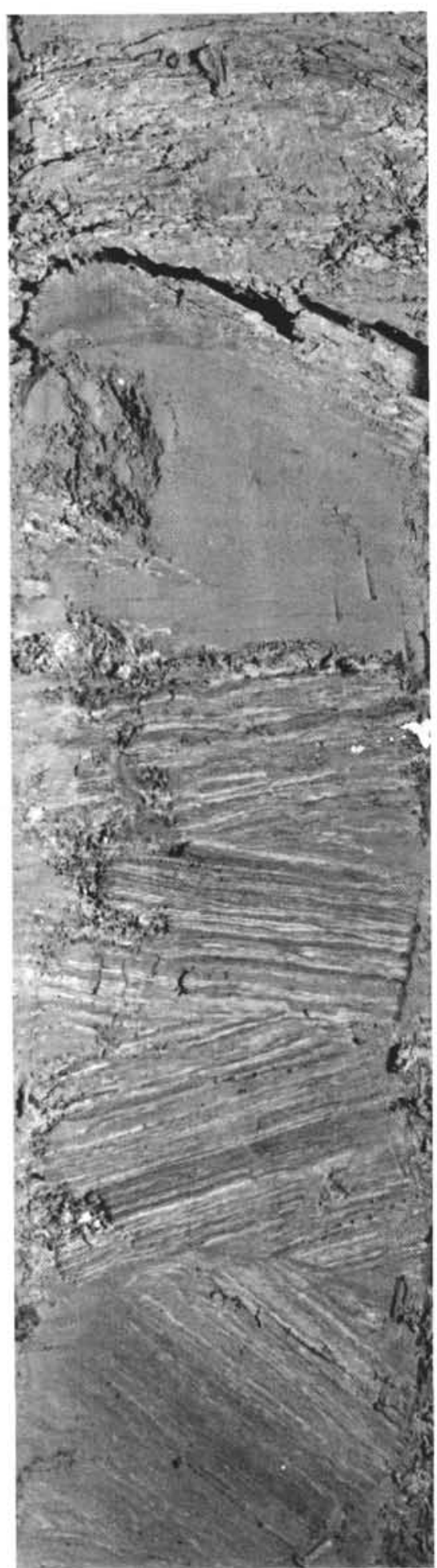

B.

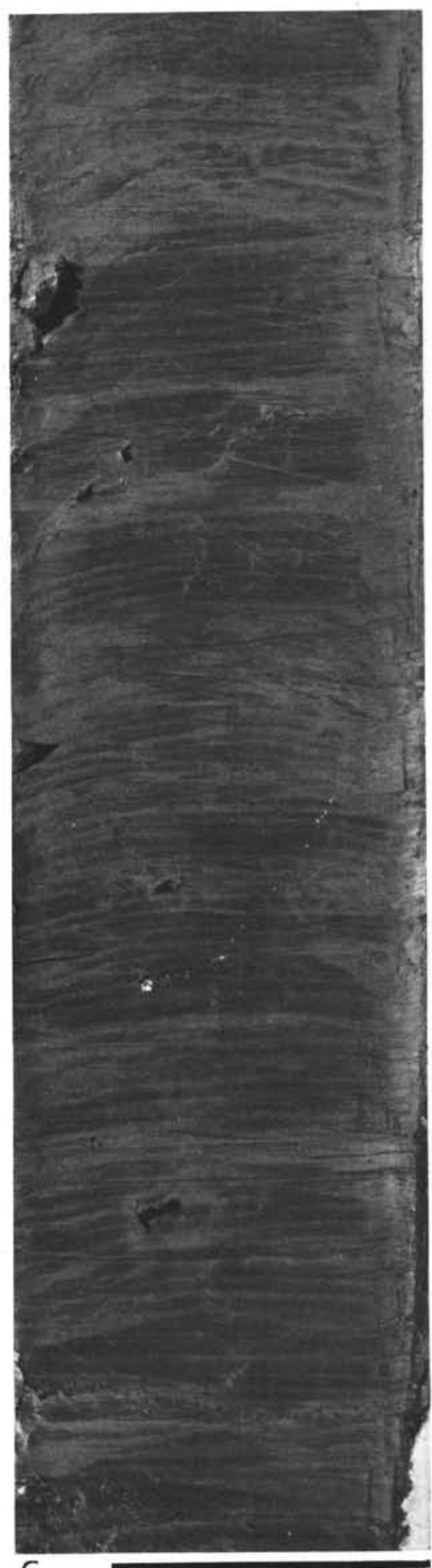

C.

Figure 6. Three typical varve patterns recognized in Pleistocene sediments of the Black Sea: (A) megavarves, (B) finely laminated carbonates, (C) Scandinavian-type post-glacial lacustrine varves.

in size and section profiles to the Black Sea burrows, have been classified as the ichnogenus (trace fossil genus) Chondrites, although the original generic description requires more regularity in branching pattern. The name Thalassinoides is used to describe more irregular but larger ramified burrows. At the level of descriptive precision and identification of such burrows used today, Chondrites ranges from shallow waters into the abyssal depths and does not relate to lithology, age, or sedimentary facies (Chamberlain, 1975). The animals that produce such burrows have not been identified, but some polychaetes (Nereis; Reineck, 


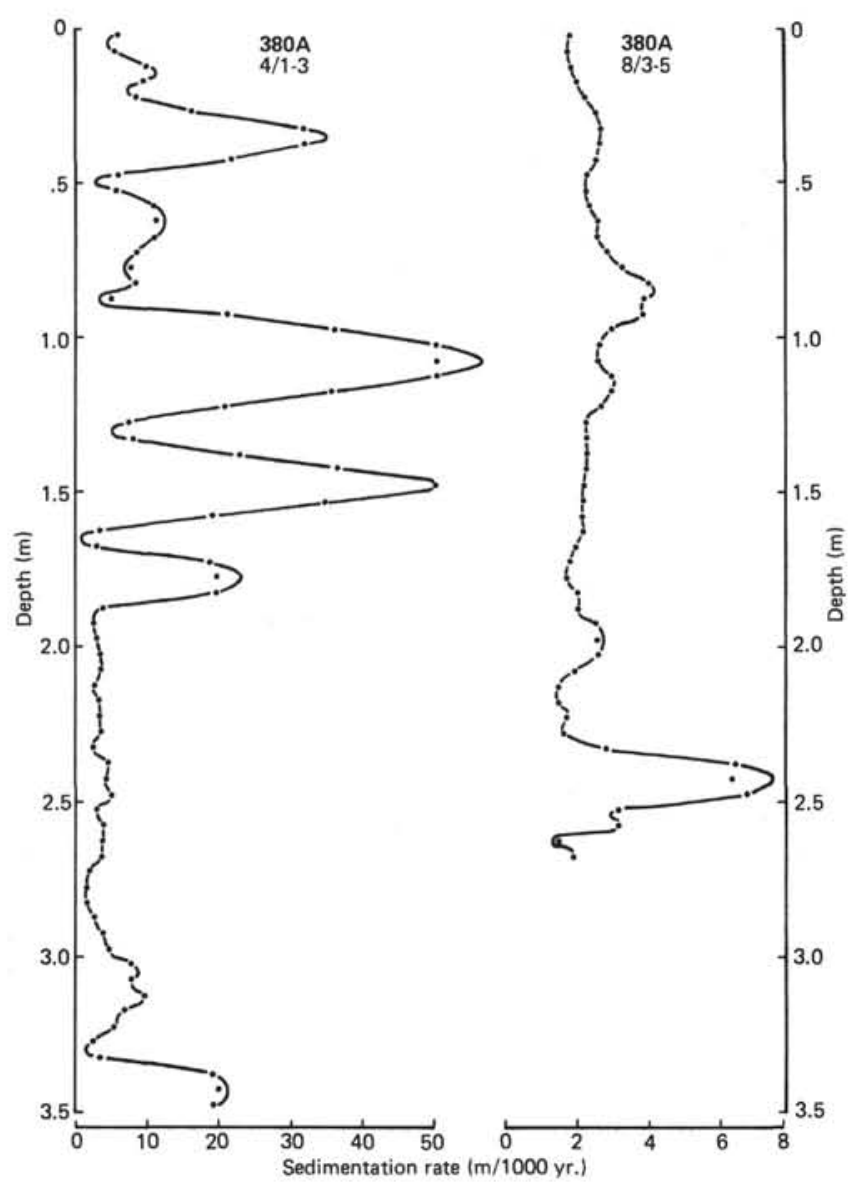

Figure 7. Rate of sedimentation of "classic" Scandinavian varves at Hole $380 \mathrm{~A}$.

1958) may represent possible candidates with respect to their size and burrowing behavior.

Within the sedimentary context, the described burrow horizons indicate discontinuous sedimentation and existence of omission surfaces (Bromley, 1975), with frequent minor turbidite layers interrupting the burrowing process, with or without erosional truncation of the preomission burrow suite. Interference of burrows of two adjacent horizons has not been observed. The rate of sedimentation and the associated energy did not permit sufficient residence time for burrowers at the sediment-water interface to produce completely reworked and mottled sediment texture. Layers with coarser sediment grains and cross bedding are indicative of even higher energies. A gradient of increased energy can be followed along the core from sections showing periods of cyclically re-occurring bioturbation interrupted by periods of higher sedimentation rates, to sections with complete dominance of physical sedimentary processes. Such gradients are generally expected to span from lower to higher energy environments, with the abundance and alternation rates of physical sedimentary structures increasing landward (Howard, 1975). Pyritic layers probably reflect occasional higher input of organic detritus.

The observed cyclic sedimentary structures are reminiscent of small scale cycles of the British Lias (Hallam, 1960, 1964; Sellwood, 1970, type II). They indicate changes from oxygenated to reducing con-

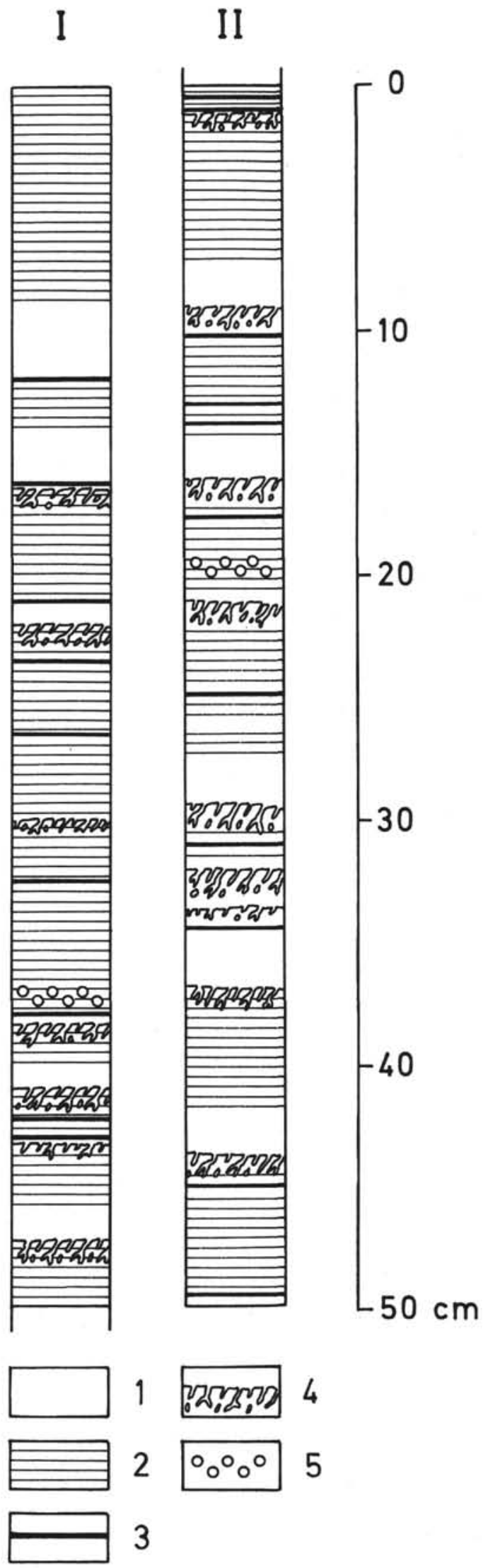

Figure 8. Megavarves, Hole 379A, Section 60-2. Legend: light colored carbonate (1); clayrich gray layer (2); pyrite layer (3); animal burrows (4); coarse-grain sediment (5). Continuous section (I and II). 
A

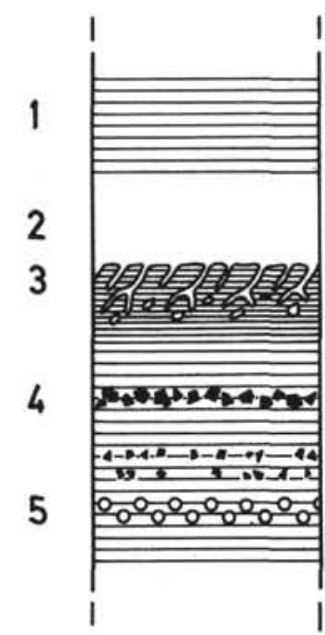

B

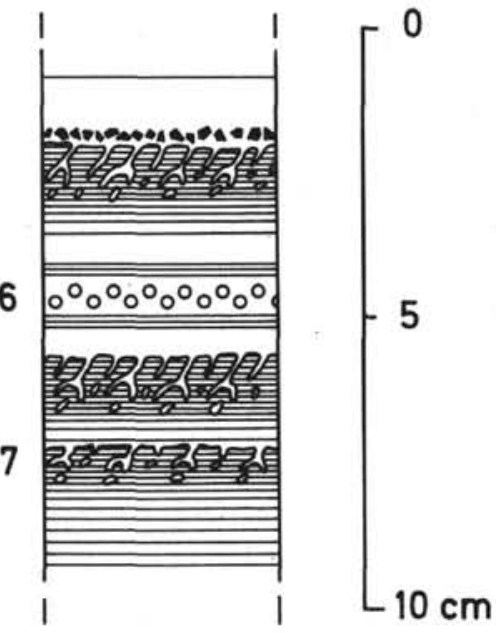

Figure 9. Megavarves; Hole 379A, Section 60-2. Legend: gray (1); white (2); burrows (3); pyrite (4); coarse gray (5); coarse white (6); truncated horizon (7).

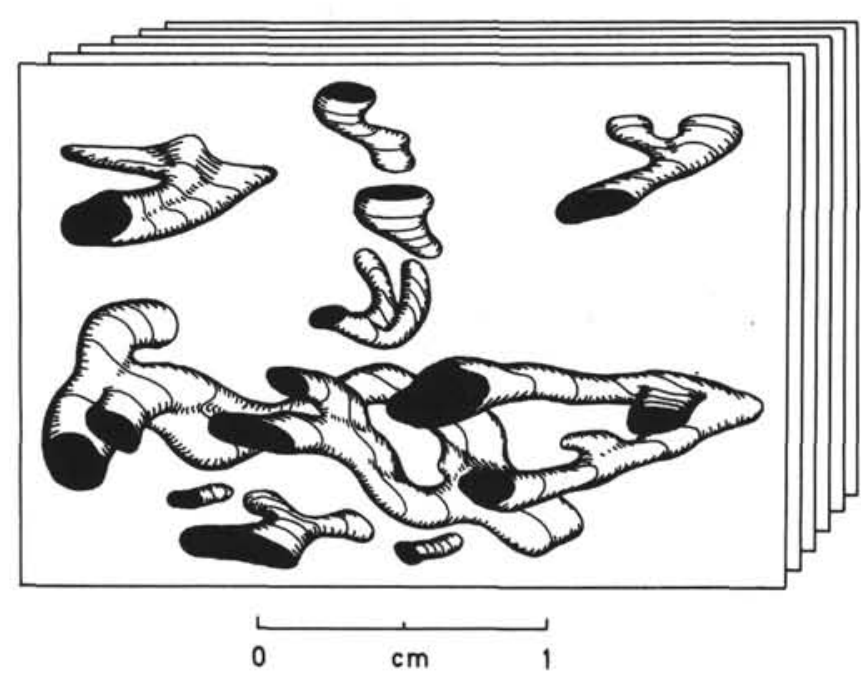

Figure 10. Serial sections of the animal burrows from Hole 379A, Section 60-2.

ditions at the sediment-water interface and vice versa, and an active and fluctuating sediment transport in a shallow basin (maximum a few hundred $\mathrm{m}$ ). They are significantly different from sediments prevalent in the present-day deep basin of the Black Sea $(\sim 2000 \mathrm{~m})$, where sequences of finely laminated reduced organicrich sediments are interrupted by thick beds $(0.2$ to $2 \mathrm{~m}$ thick) of completely homogenized fine grain turbidites. It is implied that the development of the modern Black Sea deep basin proceeded by subsidence in the time interval following the Cromerian.

\section{SEEKREIDE-SAPROPEL ALTERNATIONS}

We have stated that megavarves represent an intermediate phase in the seekreide-sapropel system. Assuming a thermohaline stratification of the water
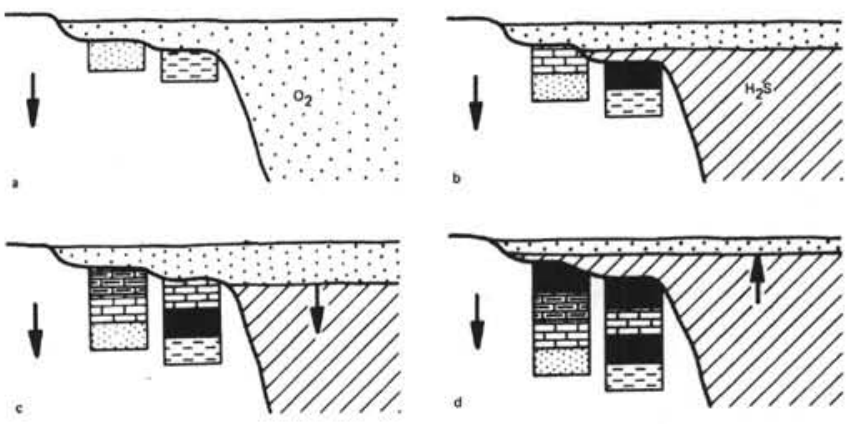

Figure 11. Formation and evolution of stratified waters (see text).

body (Degens and Stoffers, 1976), in time anoxic conditions can be created below the interface. It is essential to know that the two contrasting environments above and below the pycnocline not only differ in oxygen and hydrogen sulfide, but in a number of other chemical parameters. The carbonate system is particularly sensitive in that $\mathrm{CaCO}_{3}$ may precipitate above and dissolve below the interface. In Figure 11 we outline a scenario where a fully oxygenated environment (a) changes to a stratified one (b). With a lowered pycnocline, massive carbonate deposition will take place (c). An upward progression of the interface (d) will extend euxinic conditions to shallower parts of the basin with established benthic communities becoming extinct and carbonates starting to dissolve because the level of carbonate compensation in time will be identical with the level of the $\mathrm{O}_{2}-\mathrm{H}_{2} \mathrm{~S}$ interface; this process may continue repeatedly. As a function of speed and frequency at which the pycnocline rises and falls, a wide variety of transition structures between the two extremes (i) sapropel and (ii) Seekreide may come into existence. Water depth and distance from land also will have a decisive influence on the type of sediment. Judging by the gross physical appearance of the megavarves, water depth was probably an order of magnitude lower than at the present drilling site; a playa lake is suggested. Massive sapropel facies developed below the pycnocline in moderately deep water, that is, at a depth of perhaps a hundred to a few hundred meters, while at the same time seekreide precipitated in oxygenated shallow water.

In conclusion, all members of the Black Sea seekreide-sapropel family formed in shallow to moderately deep water; the principal controlling device was an oscillating pycnocline. Fluctuations in the $\mathrm{O}_{2}$ $\mathrm{H}_{2} \mathrm{~S}$ interface most likely were brought about by climatic changes or subsidence of the basin.

\section{REFERENCES}

Bromley, R.G., 1975. Trace fossils at omission surfaces. In Frey, R.W. (Ed.), The study of trace fossils: New York, Heidelberg, Berlin (Springer Verlag), p. 399-428.

Chamberlain, C.K., 1975. Trace fossils in DSDP cores of the Pacific: J. Paleontol., v. 49, p. 1074-1096.

Crimes, T.P., 1975. The stratigraphical significance of trace fossils. In Frey, R.W. (Ed.), The study of trace fossils: New York, Heidelberg, Berlin (Springer Verlag), p. 109-130. 
Degens, E.T. and Stoffers, P., 1976. Stratified waters-key to the past: Nature, v. 263, p. 22-27.

Degens, E.T., Paluska, A., and Eriksson, E., 1976. Rates of soil erosion. In Svensson, B.H. and Söderlund, R. (Eds.), Nitrogen, phosphorus and sulphur-global cycles: Econ. Bull. (Stockholm), v. 22, p. 185-191.

Degens, E.T., Michaelis, W., Mopper, K., and Kempe, St., in press. Warven-Chronologie holozäner Sedimente des Schwarzen Meeres: N. Jb. Geol. Paläont. Mh.

Deuser, W.G., 1971, Organic-carbon budget of the Black Sea: Deep-Sea Res., v. 18, p. 995-1004.

1974. Evolution of anoxic conditions in Black Sea during Holocene: Am. Assoc. Petrol. Geol. Mem. 20, p. 133-136.

Hallam, A., 1960. A sedimentary and faunal study of the Blue Lias of Dorset and Glamorgan: Phil. Trans. Roy. Soc. London Ser. B, v. 243, p. 1-44.

1964. Origin of the limestone-shale rhythm in the Blue Lias of England: a composite theory: J. Geol., v. 72, p. 157-169.

Hammen, T.V.D., Wijmstra, T.A., and Zagwijn, W.H., 1971. The floral record of the Late Cenozoic of Europe. In Turekian, K.K. (Ed.), Late Cenozoic Glacial ice ages: New Haven and London (Yale University Press), p. 391424.

Howard, J.D., 1975. The sedimentological significance of trace fossils. In Frey, R.W. (Ed.), The study of trace fossils: New York, Heidelberg, Berlin (Springer Verlag), p. 131-146.

Kennedy, W.J., 1975. Trace fossils in carbonate rocks. In Frey, R.W. (Ed.), The study of trace fossils: New York, Heidelberg, Berlin (Springer Verlag), p. 337-398.

Redfield, A.C., Ketchum, B.H., and Richards, F.A., 1963. The influence of organisms on the composition of seawater. In Hill, M.N. (Ed.), The sea, v. 2, New York (Interscience), p. 26-77.

Reineck, H.E., 1958. Wühlbau-Gefüge in Abhängigkeit von Sediment-Umlagerungen: Senckenb. Leth., v. 39, p. 1-23, 54-56.

Ross, D.A., and Degens, E.T., 1974. Recent sediments of Black Sea: Am. Assoc. Petrol. Geol. Mem. 20, p. 183199.

Sellwood, B.W., 1970. The relation of trace fossils to small scale sedimentary cycles in the British Lias. In Crimes, T.P. and Harper, J.C. (Eds.), Trace fossils, Geol. J. Spec. Issues 3: Liverpool (Seel House Press), p. 489-504.

Shimkus, K.M. and Trimonis, E.S., 1974. Modern sedimentation in Black Sea: Am. Assoc. Petrol. Geol. Mem. 20, p. 249-278.

Zagwijn, W.H., 1975. Chronostratigrafie en biostratigrafie: Indeling van het $\mathrm{K}$ wartair op grond van veranderingen in vegetatie en klimaat. In Zagwijn, W.H. and van Staalduinen, C.J. (Eds.), Toelichting bij Geologische Overzihtskaarten van Nederland, Haarlem, p. 109-114. 